\title{
FLAVONOIDS OF Quercus iberica
}

D. N. Enukidze, N. F. Komissarenko,

UDC 547.972 and L. I. Éristavi

In a study of the flavonoid composition of the bark and leaves of $Q$. iberica Stev., we have isolated two substances on polyamide sorbent by methods described previously [1]. From the bark we obtained substance (I), $\mathrm{C}_{15} \mathrm{H}_{10} \mathrm{O}_{7}, \mathrm{mp} 309-311^{\circ} \mathrm{C}$ and from the leaves substance (II), $\mathrm{C}_{21} \mathrm{H}_{20} \mathrm{O}_{12}, \mathrm{mp} 218-220^{\circ} \mathrm{C},[\alpha]_{\mathrm{D}}^{21}$ $-38.0^{\circ} \mathrm{C}$ (c 0.5 ; pyridine).

On the basis of their physicochemical properties, UV and IR spectra, $R_{f}$ values in various systems, and mixed melting points, these substances have been identified as quercetin and isoquercitrin, respectively.

\section{LITERATURE CITED}

1. N. F. Komissarenko, V. T. Chernobai, and D. G. Kolesnikov, Med. Prom. SSSR, 1965, No. 1, 25.

I. G. Kutateladze Institute of Pharmacochemistry, Academy of Sciences of the Georgian SSR. Khar'kov Chemical and Pharmaceutical Scientific-Research Institute. Translated from Khimiya Prirodnykh Soedinenii, No. 1, pp. 119-120, January-February, 1972. Original article submitted September $30,1971$.

- 1974 Consultants Bureau, a division of Plenum Publishing Corporation, 227 West 17th Street, New York, 1. Y. 10011. No part of this publication may be reproduced, stored in a retrieval system, or transmitied, in any form or by any means, electronic, mechanical, photocopying, microfilming, recording or otherwise, without uritten permission of the publisher. 1 copy of this article is available from the publisher for $\$ 15.00$. 